\title{
The persistence of active fund management performance
}

\author{
D.R. Wessels and J.D. Krige* \\ Graduate School of Business, University of Stellenbosch, \\ PO Box 610, Bellville 7535, Republic of South Africa \\ jdkrige@sun.ac.za
}

Received March 2005

\begin{abstract}
This study focuses on the performance persistence of equity funds in the South African Unit Trust Industry against its appropriate index benchmark (ALSI) over the period 1988 to 2003. A few funds exhibited extraordinary persistence - either in out-performing or under-performing. In general it was found that over the short term (month-to-month and quarter-to-quarter basis) there was a tendency that the current performance of a fund would be repeated, with a greater tendency among the top performing funds to remain a top performer.
\end{abstract}

However, when the persistence of fund performance was measured on a year-to-year basis, less consistency among funds was identified. The decile ranking movement of a fund - upwards, downwards or sideways became more random in nature. When the forward-looking period was extended to three years, however, the chances that the fund would have stayed in the same decile became very slim.

Herein lies the danger of placing your trust with one active manager only; over the long run the performance ranking of managers can assume a random nature if manager skill is not persistent.

*To whom all correspondence should be addressed.

\section{Introduction}

The active manager's best proof of ability to outperform the market is found in his or her performance track record and serves as the criterion on which the manager is judged and selected. Professional investment advisors and the media devote much time and energy to study and document the past performance of mutual funds on the premise that an analysis thereof would indicate future winners. However, question marks are raised around the consistency of performance and whether past performance is a reliable indicator of future performance.

Section 2 presents a literature overview. The persistence analysis is executed in Section 3 and a final section concludes and summarises.

\section{Literature review}

The efficient market hypothesis implies among other that past performance is no guarantee of future performance, the average manager will not be able to beat a passive strategy, and top managers will not be expected to outperform in future. Excess performance is the result of luck, not skill. Further, track records are useful for evaluating the riskiness of managers' strategies, but not to ascertain the skill of managers (Goetzmann \& Ibbotson, 1994).
Michael Jensen studied mutual fund performance over the period 1945-1964 and concluded that not only the average fund performance, but also individual performance was no better than that predicted from mere random chance. Later studies confirmed Jensen's view, but some such as those done by Hendricks, Patel and Zeckhauser (1993) came to contrary conclusions where some consistency in winning and losing funds was found.

Goetzmann and Ibbotson (1994) established in their studies done on raw returns, risk-adjusted alpha returns and stylecategorised groups that past returns and relative rankings were useful in predicting the returns and rankings of mutual funds. The top-quartile performers were most likely to be in the same quartile in successive periods, and the lower the initial ranking the worse the subsequent performance.

Studies by Kahn and Rudd (1995) focused on whether past performance carried any information regarding future performance. It differed from the majority of previous studies by making use of a style analysis method. Mutual funds were categorised into growth versus value and large cap versus small cap orientated styles. Hereby style returns were separated from selection returns. For example, if value managers outperformed the broad market index (S\&P 500) over two review periods an alpha analysis might have indicated persistence, but not when done on the style analysis method. With the latter method a value manager would be evaluated with a value index over both periods and then whether persistence existed. They did not find evidence 
of performance persistence among equity mutual funds, before and after accounting for expenses. Their conclusion was that with no persistence of selection returns investors would be better off to make use of index investing, which due to its low cost would yield better returns than the median of active funds. They further noted that survivorship bias would make it appear that winners repeat. Through Monte Carlo simulation studies it was proved that the tstatistic of surviving funds' persistence was enhanced by increasing the cut-off percentage of funds at the bottom of performance rankings.

Elton, Gruber and Blake (1996) studied the predictability of stock mutual funds using risk-adjusted returns and concluded that funds that did well in the past continued to do well in the future on a risk-adjusted basis. They found that both one- and three-year alphas conveyed information about future performance, but one-year performance periods conveyed much more information about future performance than three-year periods.

When optimal portfolios based on past information were formulated it led to a positive and statistically significant return compared to a portfolio where funds were equally weighted. Elton, et al. (1996) concluded that the differences between the top and bottom performance deciles were attributed to differences in selection skill and expenses.

Carhart (1997) suggested that persistence in mutual fund performance did not reflect superior stock-picking skill, but was rather explained by common factors in stock returns and differences in fund expenses and transaction costs. It was found that performance persistence among funds was shortlived and mostly eliminated after one year. Except for the persistent underperformance of the worst-performing funds the mean returns across deciles did not differ statistically significantly after one year.

For example, when following a strategy of buying last year's top-decile funds and selling last year's bottom-decile funds a significant difference in return between the deciles was noted after one year. Most of the spread between the deciles could be explained by differences in the momentum of stock return and investment costs between funds. Over the longer term these differences narrowed and except for the bottom decile could be explained mostly by common stock factors and investment costs.

Zheng (1999) investigated whether investors' purchasing and selling decisions were able to predict funds' future performances, thus whether investors in general were smart in selecting funds. Evidence was found that funds that received more inflows subsequently perform significantly better than those that have had a net outflow. He noted that previous studies reported that money flows into past good performers and flows out of past poor performers. The studies by Goetzmann and Ibbotson (1994) and Carhart (1997) suggested that past performance persisted at least over the short term. These two phenomena indicated that active fund investors might have had selection ability. The study supported the "smart money" effect. Investors were able to select funds by divesting from poor performers and investing in good performers as the latter group outperformed the former over the short term (on average 30 months).

However, Zheng (1999) reported that when constructing a portfolio of funds with net inflows, no abnormal positive returns over the market returns were evident. Investors' cash flow could not be used to predict or earn abnormal returns, thus the 'smart money' effect carried no information value.

Chavalier and Ellison (1999) examined whether mutual fund performance was related to the characteristics of fund managers. Most of the raw differences in fund returns could be explained by differences in risk, expenses and investment styles. However, some differences remained. By isolating the style, risk and expense differences the inherent characteristics of the fund manager were an important dividing line between good and bad performance.

For example, managers that attended more selective tertiary institutions had higher returns on average than those managers who attended less selective institutions. Superior stock-picking ability existed for a subgroup of managers and could be explained by differences in inherent abilities, benefits from better education, value of social networks or difference in the characteristics of fund management companies that hire managers from the different schools.

In summary, many studies were done on the persistence of mutual fund returns, but with different conclusions reached. Some found no persistence; others experienced persistence at least over the short term. The difference in conclusions, as noted by Kahn and Rudd (1995), could be attributed to the different evaluation methods used, the effect of survivorship bias, whether accounted for fees or not, and the integrity of databases used.

On balance it seems that short-term persistence, whether good or bad, was found, but vanished over longer review periods. The difference between the top performing funds and the worst performing funds could be ascribed to a combination of differences in managers' skill, expense ratios and the momentum effect of stock return.

Some studies have been done in South Africa over the last number of years to evaluate performance persistence. The findings from a few of these research studies are subsequently highlighted. Bradfield and Swartz (2001) analysed the persistence of general equity unit trusts over the period 1995 to 2001. They found that some top performing funds consistently delivered superior returns and concluded that those managers possessed significant skill to outperform their peers.

Gopi, Bradfield and Maritz (2004) elaborated on the work done by Bradfield and Swartz (2001). They found a high degree of persistence among the top quartile funds when evaluated on a quarterly forward-looking basis, while the worst-performing funds showed persistence in poor performance. However, when the forward-looking basis was extended to two quarters (6 months) the persistence declined. The top quartile funds still exhibited significant persistence, but the inter-quartile movements in the other quartile groups became more random in nature. 
When evaluating two possible fund allocation (fund-offunds) strategies, based on a quarterly and annual 'lookback' period respectively, it was found that a strategy of allocating funds to top quartile funds would have yielded the highest return in both cases. Furthermore, the quarterly 'look-back' strategy yielded a better return than the annual 'look-back' strategy. This could be explained by short-term trending or momentum effects, but the quarterly 'look-back' strategy would only be feasible if substantial discounted fees could be negotiated.

Oosthuizen and Smit (2002) applied the evaluation techniques used by Zheng (1999) to establish whether South African unit trust investors displayed ex ante selection ability of investing in funds that would perform better. The results from the analysis indicated that investors on aggregate displayed a weak, but statistically significant, skill in identifying winners. Nonetheless, no evidence was found that investors could beat the market by investing in funds with positive money flows. Thus, similar to the findings of Zheng (1999), the 'smart money' effect carried no information value.

\section{Persistence analysis}

\section{Methodology}

Unit price data from the McGregor Raid Station database, available at the University of Stellenbosch Business School, were used to evaluate the historic performance of active fund managers. By ranking the performance of the actively managed funds in each period, the persistence of funds following their rankings in subsequent periods could be established. Further, the tendency of relative performance to be repeated over different forward-looking or successive periods could be determined in order to gauge whether persistence in general existed or not.

Performance rankings, in terms of percentiles, deciles and quartiles, were done following the statistical convention where, for example the $25^{\text {th }}$ percentile (first or bottom quartile) performance would have been that value corresponding to the point below which $25 \%$ of the observations lie (75\% of the observations are above this value). Similarly, a $75^{\text {th }}$ percentile performance (third or top quartile) will be that value corresponding to the point above which $25 \%$ of the observations lie (75\% of the observations are below this value). Deciles were ranked from 1 to 10 , with 1 the lowest and 10 the highest ranking.

Performance data were used from the "after-cost" analysis over rolling three, five and ten year investment periods and the results from the analysis are subsequently discussed.

\section{Results}

\section{Quartile ranking}

The quartile ranking of active funds and their relative persistence of performance over the three rolling periods are exhibited in Figures 1 - 3. Notable is the consistent performance of a few funds, either in the top or bottom quartile.
Active funds such as Allan Gray Equity and Oasis Crescent Equity performed consistently in the top quartile over rolling 36-month periods, while FNB Growth and Investec Equity together with Allan Gray Equity did exceptionally well over 60-month periods. Over the rolling ten year investment period Investec Equity and Futuregrowth Albaraka had an excellent track record.

On the other side of the performance scale some active funds, like Coris Capital General Equity, Nedbank Equity, Tri-Linear Equity, MCubed Equity, Stanlib Capital Growth, ABSA General Equity and Sanlam General Equity fared poorly consistently.

\section{Percentile Ranking}

Percentile rankings of the actively managed funds are shown in Tables 1 - 3. Some funds, like Allan Gray Equity, Oasis Crescent, FNB Growth, Investec Equity and Futuregrowth Albaraka had shown exceptional persistence in achieving top performance rankings over the different rolling periods. By the same token some funds, like Nedbank Equity, Absa General Equity, Sanlam General Equity and Stanlib Capital Growth had a similar persistence, but only to underperform.

Otherwise there was a relatively wide dispersion in the persistence of performance over the rolling investment periods. If the index performance is ranked relative to the active fund performance, it can be seen that the index performance ranked at about the $60^{\text {th }}$ percentile over the periods, but with large deviations in between.

\section{Beating the Index}

Besides the persistence of performance it is also relevant to what extent active funds were repeatedly able to beat the index. The percentage success rate of each active fund in outperforming the index is shown in Table 4.

When considering the number of periods under review the Investec Equity fund had a high success rate in beating the index. To a lesser extent funds like Futuregrowth Albaraka Equity and Metropolitan General Equity funds had good successes. The Allan Gray Equity and Oasis Crescent Equity had a $100 \%$ success rate, but with considerably less review periods than the earlier-mentioned equity funds.

\section{Predictability of performance}

In the analysis thus far it has been established that some funds exhibited exceptional persistence in keeping their relative performance rankings. Other funds again showed large deviations from their average ranking. Beside this knowledge one would like to ascertain to what extent the persistence information could be used as a tool to predict performance. For example, if a fund is delivering a good performance now, what are the probabilities that it will still be a good performer in twelve months' time? 


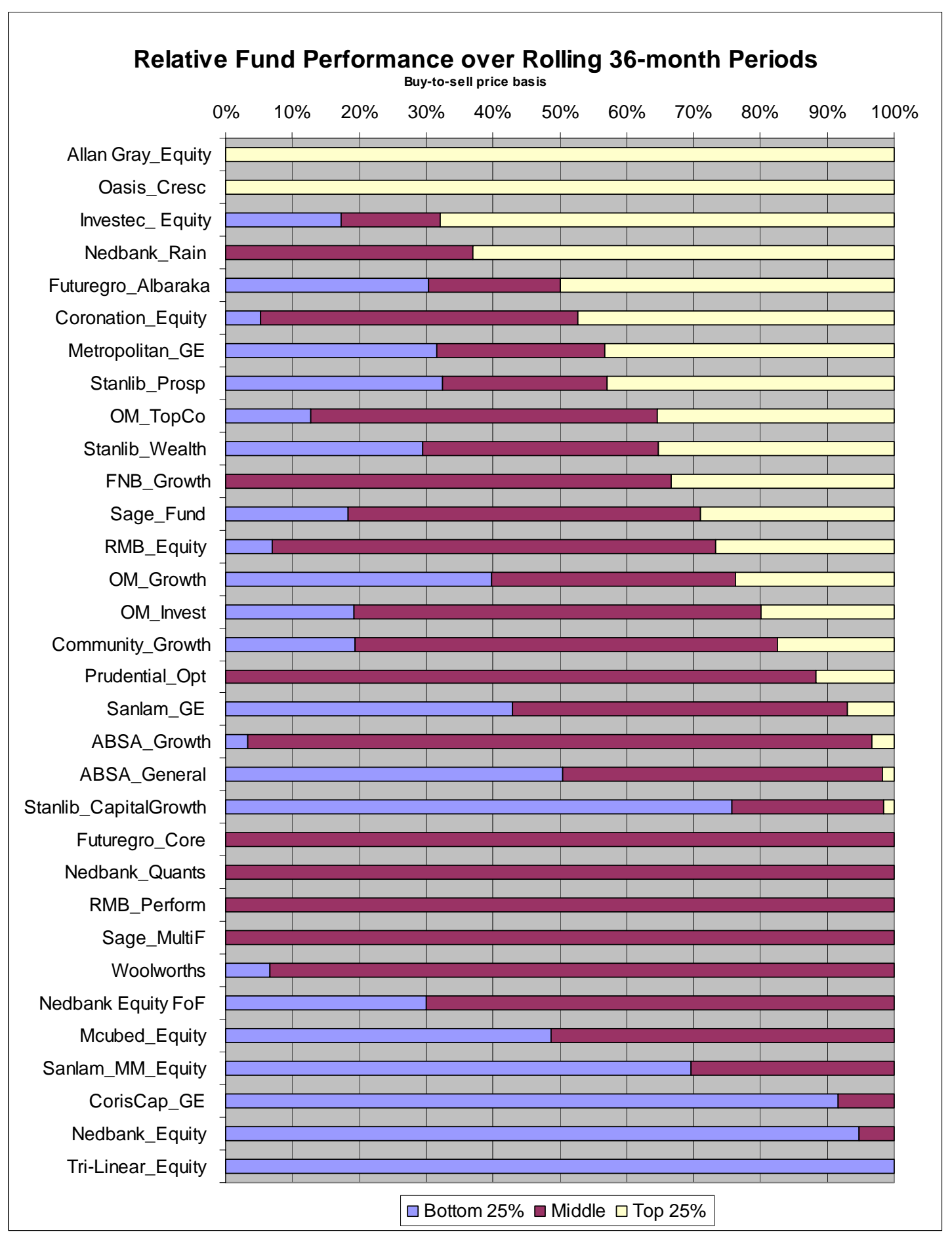

Figure 1: Quartile ranking of actively managed funds over rolling 36 month investment periods 


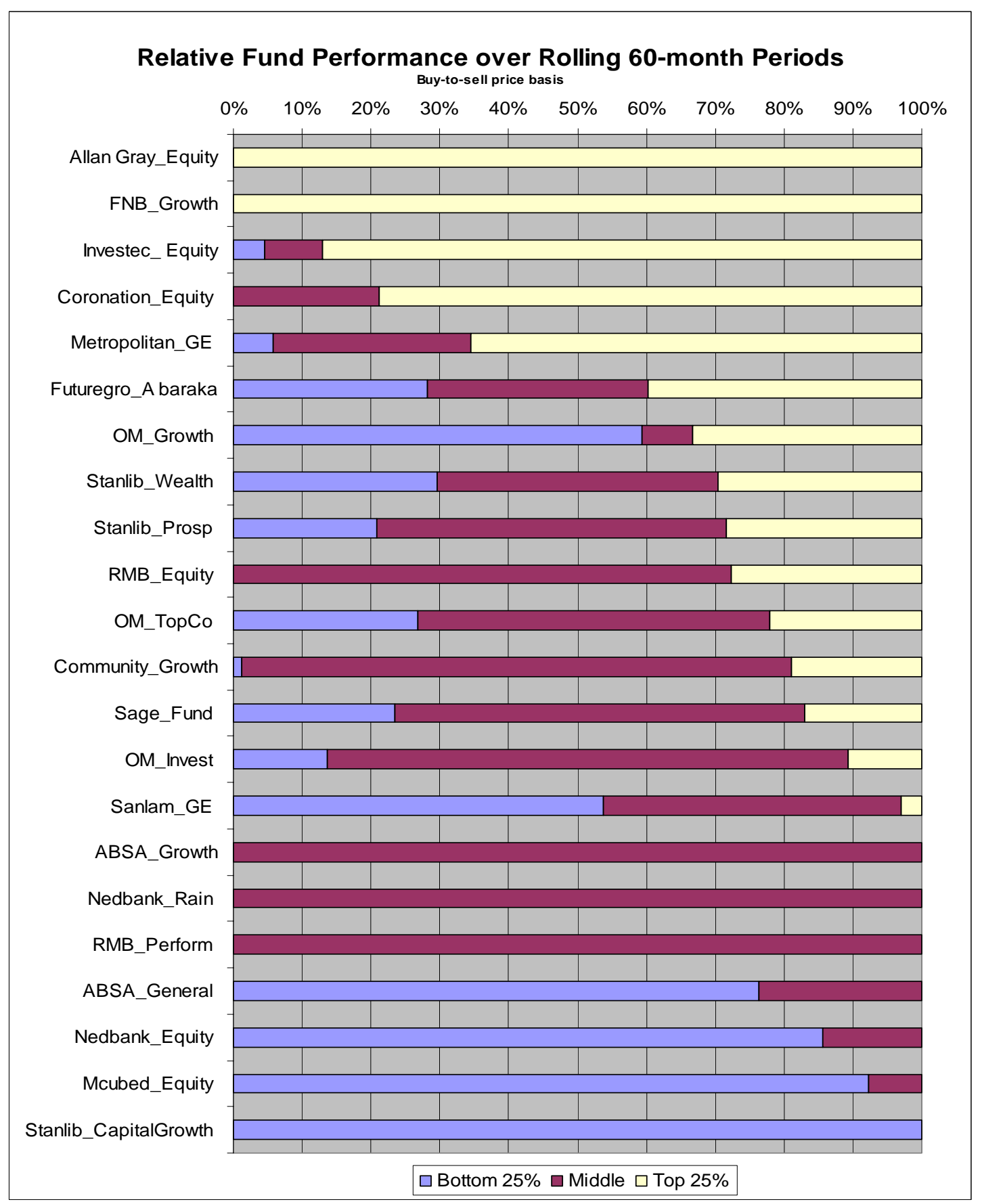

Figure 2: Quartile ranking of actively managed funds over rolling 60-month investment periods 


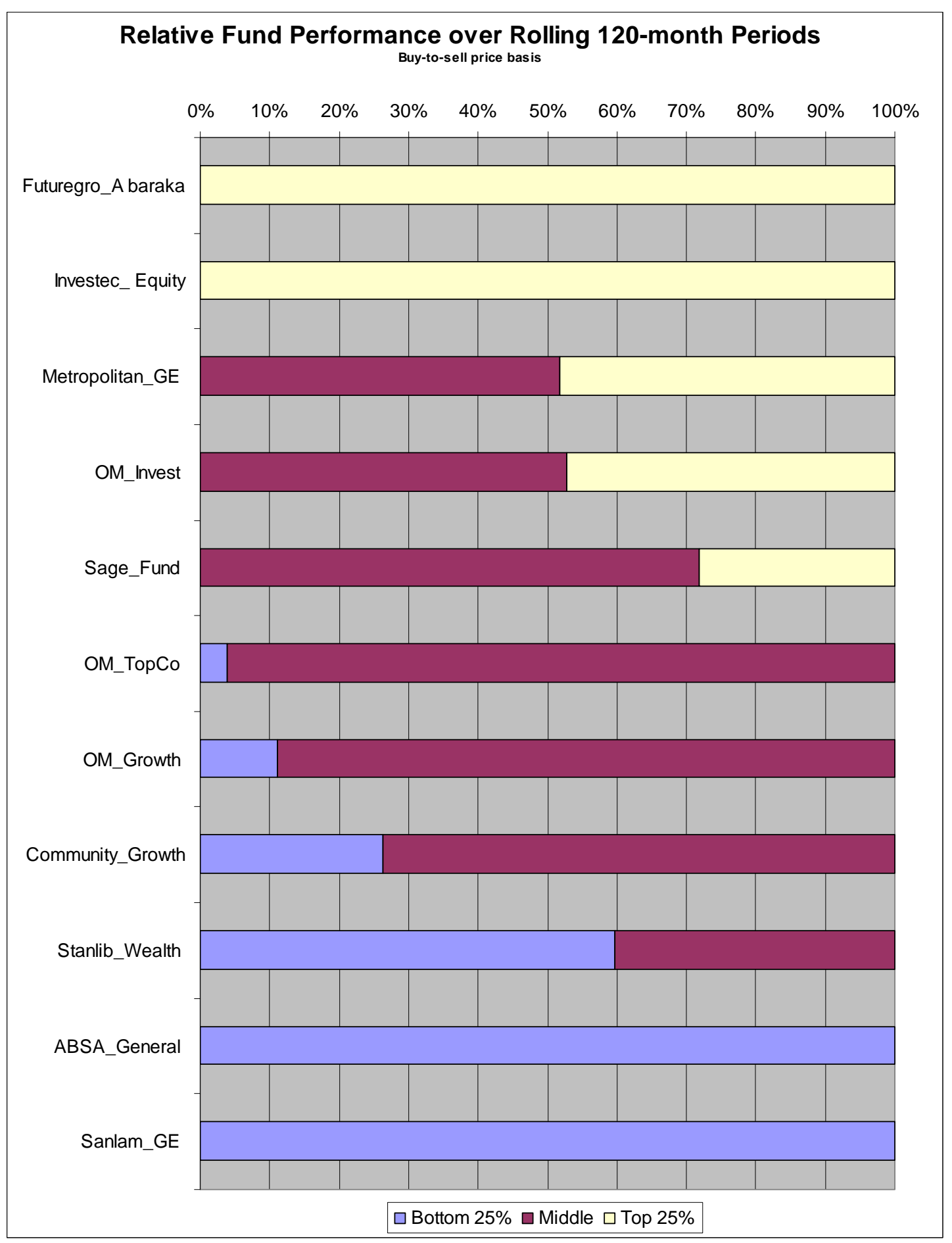

Figure 3: Quartile ranking of actively managed funds over rolling 120-month investment periods 
Table 1: Percentile ranking of actively managed funds over rolling 36-month investment periods

\begin{tabular}{|c|c|c|c|c|c|}
\hline Fund & Periods & Average Percentile & Std Dev & $\begin{array}{c}\text { Min Decile } \\
\text { Ranking } \\
\end{array}$ & $\begin{array}{c}\text { Max Decile } \\
\text { Ranking } \\
\end{array}$ \\
\hline Allan Gray_Equity & 27 & 96 & 5 & 9 & 10 \\
\hline Oasis Cresc & 13 & 94 & 5 & 9 & 10 \\
\hline Nedbank_Rain & 27 & 71 & 27 & 2 & 9 \\
\hline Sage MultiF & 4 & 70 & 0 & 7 & 7 \\
\hline FNB_Growth & 27 & 68 & 11 & 5 & 9 \\
\hline Investec Equity & 156 & 68 & 33 & 1 & 10 \\
\hline Coronation_Equity & 57 & 65 & 31 & 1 & 10 \\
\hline Prudential Opt & 17 & 64 & 6 & 6 & 8 \\
\hline Futuregro_Albaraka & 102 & 57 & 37 & 1 & 10 \\
\hline RMB Equity & 71 & 54 & 19 & 2 & 8 \\
\hline Metropolitan_GE & 111 & 53 & 41 & 1 & 10 \\
\hline OM ТорСо & 110 & 50 & 28 & 1 & 10 \\
\hline Stanlib_Wealth & 156 & 50 & 35 & 1 & 10 \\
\hline Sage Fund & 148 & 49 & 24 & 1 & 10 \\
\hline Futuregro_Core & 24 & 49 & 6 & 4 & 6 \\
\hline OM Invest & 156 & 49 & 24 & 1 & 10 \\
\hline Stanlib_Prosp & 77 & 48 & 35 & 1 & 9 \\
\hline Community Growth & 103 & 46 & 22 & 1 & 9 \\
\hline Nedbank_Quants & 14 & 45 & 13 & 2 & 6 \\
\hline OM Growth & 93 & 44 & 33 & 1 & 9 \\
\hline ABSA_Growth & 30 & 41 & 12 & 2 & 7 \\
\hline RMB Perform & 30 & 39 & 10 & 2 & 6 \\
\hline Nedbank Equity FoF & 20 & 34 & 20 & 1 & 6 \\
\hline Sanlam GE & 156 & 32 & 24 & 1 & 10 \\
\hline Woolworths & 15 & 31 & 9 & 2 & 5 \\
\hline ABSA General & 117 & 25 & 22 & 1 & 8 \\
\hline Mcubed_Equity & 37 & 23 & 10 & 1 & 5 \\
\hline Sanlam MM Equity & 23 & 19 & 9 & 1 & 4 \\
\hline Stanlib_CapitalGrowth & 62 & 16 & 25 & 1 & 9 \\
\hline CorisCap GE & 12 & 9 & 11 & 1 & 4 \\
\hline Nedbank_Equity & 38 & 5 & 9 & 1 & 4 \\
\hline Tri-Linear Equity & 13 & 5 & 5 & 1 & 1 \\
\hline ALSI Index & 156 & 59 & 32 & 1 & 10 \\
\hline
\end{tabular}


Table 2: Percentile ranking of actively managed funds over rolling 60-month investment periods

\begin{tabular}{|c|c|c|c|c|c|}
\hline Fund & Periods & Average Percentile & Std Dev & Min Decile Ranking & $\begin{array}{c}\text { Max Decile } \\
\text { Ranking }\end{array}$ \\
\hline Allan Gray_Equity & 3 & 100 & 0 & 10 & 10 \\
\hline FNB_Growth & 3 & 90 & 0 & 9 & 9 \\
\hline Investec_Equity & 132 & 84 & 24 & 1 & 10 \\
\hline Coronation_Equity & 33 & 78 & 20 & 3 & 10 \\
\hline Metropolitan_GE & 87 & 76 & 27 & 1 & 10 \\
\hline Nedbank_Rain & 3 & 70 & 0 & 7 & 7 \\
\hline RMB_Equity & 47 & 55 & 16 & 3 & 9 \\
\hline Futuregro_Albaraka & 78 & 53 & 36 & 1 & 10 \\
\hline ABSA_Growth & 6 & 52 & 8 & 4 & 6 \\
\hline Community_Growth & 79 & 51 & 20 & 2 & 8 \\
\hline OM_TopCo & 86 & 49 & 23 & 2 & 8 \\
\hline OM_Invest & 132 & 49 & 18 & 1 & 8 \\
\hline Stanlib_Prosp & 53 & 48 & 23 & 1 & 9 \\
\hline Sage_Fund & 124 & 48 & 21 & 1 & 9 \\
\hline Stanlib_Wealth & 132 & 45 & 32 & 1 & 10 \\
\hline RMB_Perform & 6 & 37 & 8 & 3 & 5 \\
\hline OM_Growth & 69 & 36 & 34 & 1 & 9 \\
\hline Sanlam_GE & 132 & 19 & 21 & 1 & 8 \\
\hline Mcubed_Equity & 13 & 17 & 5 & 1 & 2 \\
\hline ABSA_General & 93 & 13 & 19 & 1 & 6 \\
\hline Nedbank_Equity & 14 & 11 & 9 & 1 & 3 \\
\hline Stanlib_CapitalGrowth & 38 & 1 & 4 & 1 & 2 \\
\hline ALSI Index & 132 & 65 & 26 & 1 & 10 \\
\hline
\end{tabular}

Table 3: Percentile ranking of actively managed funds over rolling 120-month investment periods

\begin{tabular}{|c|c|c|c|c|c|}
\hline Fund & Periods & Average Percentile & Std Dev & Min Decile Ranking & $\begin{array}{c}\text { Max Decile } \\
\text { Ranking }\end{array}$ \\
\hline Investec_Equity & 72 & 99 & 3 & 9 & 10 \\
\hline Futuregro Albaraka & 18 & 88 & 9 & 8 & 10 \\
\hline Metropolitan_GE & 27 & 66 & 14 & 5 & 8 \\
\hline OM Invest & 72 & 64 & 11 & 3 & 8 \\
\hline Sage_Fund & 64 & 59 & 11 & 4 & 8 \\
\hline OM ТорСо & 26 & 39 & 13 & 2 & 7 \\
\hline Community_Growth & 19 & 36 & 13 & 2 & 6 \\
\hline OM Growth & 9 & 29 & 3 & 2 & 3 \\
\hline Stanlib_Wealth & 72 & 24 & 15 & 1 & 7 \\
\hline Sanlam GE & 72 & 8 & 8 & 1 & 2 \\
\hline ABSA_General & 33 & 0 & 0 & 1 & 1 \\
\hline ALSI Index & 72 & 57 & 21 & 1 & 9 \\
\hline
\end{tabular}


Table4: Consistency of Actively Managed Funds in Beating the ALSI Index

\begin{tabular}{|c|c|c|c|c|c|c|}
\hline \multirow[b]{2}{*}{ Funds } & \multicolumn{2}{|c|}{$\begin{array}{c}\text { Rolling } \\
\text { Three Year Period }\end{array}$} & \multicolumn{2}{|c|}{$\begin{array}{c}\text { Rolling } \\
\text { Five Year Period } \\
\end{array}$} & \multicolumn{2}{|c|}{$\begin{array}{c}\text { Rolling } \\
\text { Ten Year Period } \\
\end{array}$} \\
\hline & Periods & $\begin{array}{c}\text { Percentage } \\
\text { Outperforming } \\
\end{array}$ & Periods & $\begin{array}{c}\text { Percentage } \\
\text { Outperforming } \\
\end{array}$ & Periods & $\begin{array}{c}\text { Percentage } \\
\text { Outperforming } \\
\end{array}$ \\
\hline ABSA_General & 117 & $16 \%$ & 93 & $15 \%$ & 33 & $0 \%$ \\
\hline ABSA Growth & 30 & $0 \%$ & 6 & $0 \%$ & & \\
\hline Allan Gray_Equity & 27 & $100 \%$ & 3 & $100 \%$ & & \\
\hline Community Growth & 103 & $37 \%$ & 79 & $37 \%$ & 19 & $26 \%$ \\
\hline CorisCap_GE & 12 & $8 \%$ & & & & \\
\hline Coronation Equity & 57 & $40 \%$ & 33 & $48 \%$ & & \\
\hline Futuregro_Albaraka & 102 & $48 \%$ & 78 & $47 \%$ & 18 & $100 \%$ \\
\hline Futuregro Core & 24 & $8 \%$ & & & & \\
\hline Investec_Equity & 156 & $62 \%$ & 132 & $74 \%$ & 72 & $100 \%$ \\
\hline FNB Growth & 27 & $41 \%$ & 3 & $100 \%$ & & \\
\hline Mcubed_Equity & 37 & $3 \%$ & 13 & $0 \%$ & & \\
\hline Metropolitan GE & 111 & $44 \%$ & 87 & $57 \%$ & 27 & $48 \%$ \\
\hline Nedbank_Equity & 38 & $0 \%$ & 14 & $0 \%$ & & \\
\hline Nedbank Equity FoF & 20 & $0 \%$ & & & & \\
\hline Nedbank_Rain & 27 & $59 \%$ & 3 & $67 \%$ & & \\
\hline Nedbank Quants & 14 & $7 \%$ & & & & \\
\hline Oasis_Cresc & 13 & $100 \%$ & & & & \\
\hline OM Growth & 93 & $46 \%$ & 69 & $33 \%$ & 9 & $0 \%$ \\
\hline OM_Invest & 156 & $31 \%$ & 132 & $17 \%$ & 72 & $51 \%$ \\
\hline OM TopCo & 110 & $39 \%$ & 86 & $45 \%$ & 26 & $31 \%$ \\
\hline Prudential_Opt & 17 & $29 \%$ & & & & \\
\hline RMB Equity & 71 & $42 \%$ & 47 & $17 \%$ & & \\
\hline RMB_Perform & 30 & $3 \%$ & 6 & $0 \%$ & & \\
\hline Sage Fund & 148 & $42 \%$ & 124 & $22 \%$ & 64 & $44 \%$ \\
\hline Sage_MultiF & 4 & $100 \%$ & & & & \\
\hline Sanlam GE & 156 & $26 \%$ & 132 & $9 \%$ & 72 & $1 \%$ \\
\hline Sanlam_MM_Equity & 23 & $0 \%$ & & & & \\
\hline Stanlib CapitalGrowth & 62 & $13 \%$ & 38 & $0 \%$ & & \\
\hline Stanlib_Prosp & 77 & $17 \%$ & 53 & $15 \%$ & & \\
\hline Stanlib Wealth & 156 & $21 \%$ & 132 & $19 \%$ & 72 & $4 \%$ \\
\hline Tri-Linear_Equity & 13 & $0 \%$ & & & & \\
\hline Woolworths & 15 & $7 \%$ & & & & \\
\hline
\end{tabular}

The performance data of the rolling three year period was selected to test the information value of performance persistence, because it had more periods (156) to analyse and, secondly, it had more funds than those in the other rolling periods to establish any trends.

By studying the past track records of the active funds it was possible to derive probabilities that a similar performance in successive periods would be repeated. Different successive periods were selected, namely monthly, quarterly, yearly and three-yearly. Further, to identify whether top performing funds had a greater chance to repeat performance the funds were split into three groups according to their average percentile ranking, specifically the top third, middle third and bottom third funds.

Table 5 illustrates the tendency of fund performance to be repeated over the different successive periods - either in the same decile, or alternatively to change to another decile; thus either improving or weakening the performance profile. If no or little persistence existed, one would expect that the movement between successive periods would assume a random character, thus roughly a 30\% movement to any of the three decile positions.

From Table 5 it is observed that fund performance tends to persist over the short-term successive periods. In particular, top performing funds tend to repeat their performance. The top funds also exhibited lower tendencies to weaken their decile rankings than the bottom third or middle third groups.

When the successive period was extended to one year forward the movements to the different decile positions became more random in nature. The top performing group showed a slightly higher tendency to repeat performance 
than the other two groups, but in essence persistence disappeared.

Over a three-year successive period it was found that the likelihood that a fund would have remained in the same performance decile was very slim, but rather tended to move into lower performance deciles than higher rankings. Notable is that the top performing funds had a higher tendency to drop performance than the other two groups over the three-year forward-looking period.

The findings from the analysis are graphically displayed in Figures 4 - 7.

Table 5: Relative movement of actively managed funds between deciles over different forward-looking periods

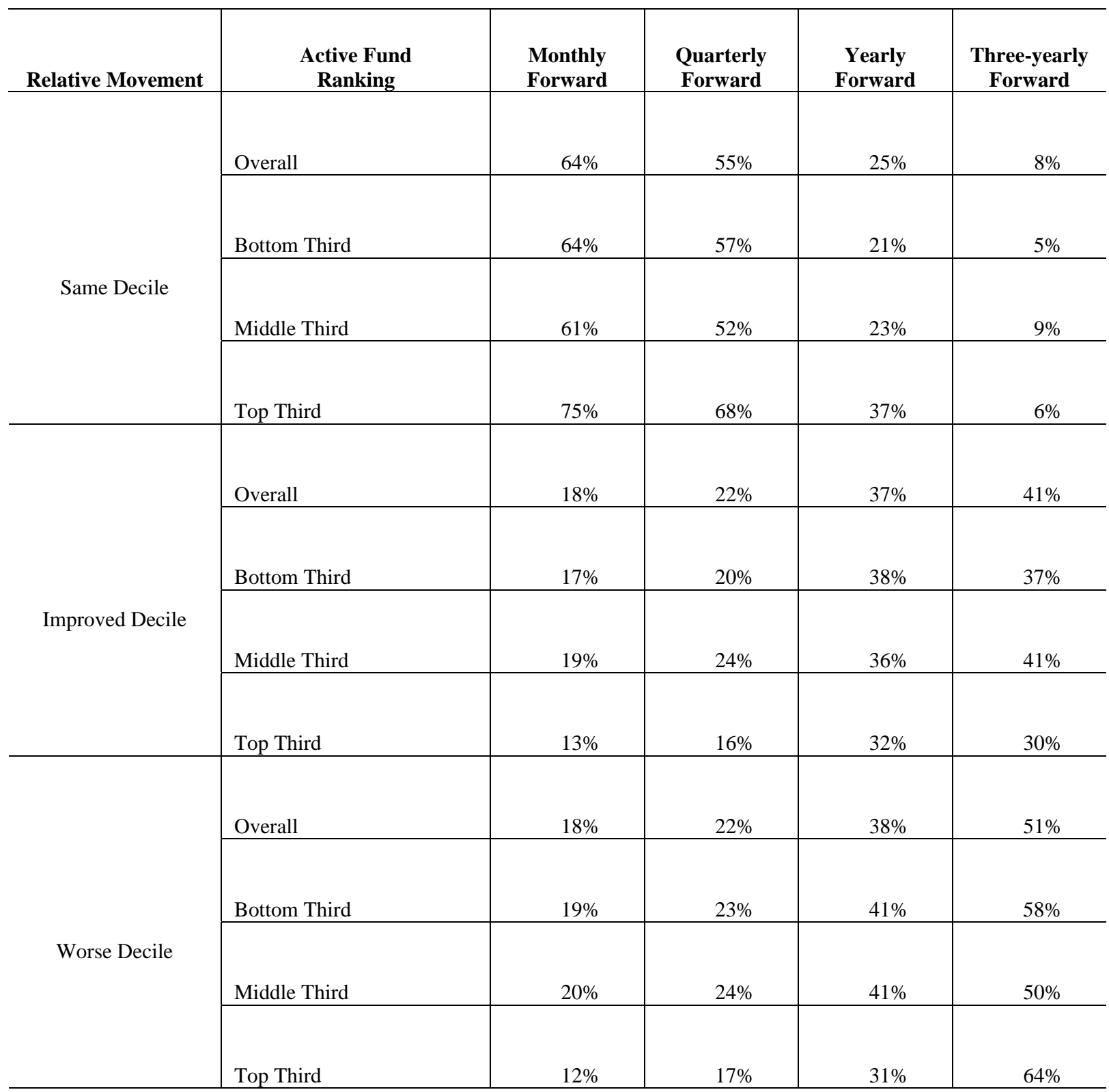




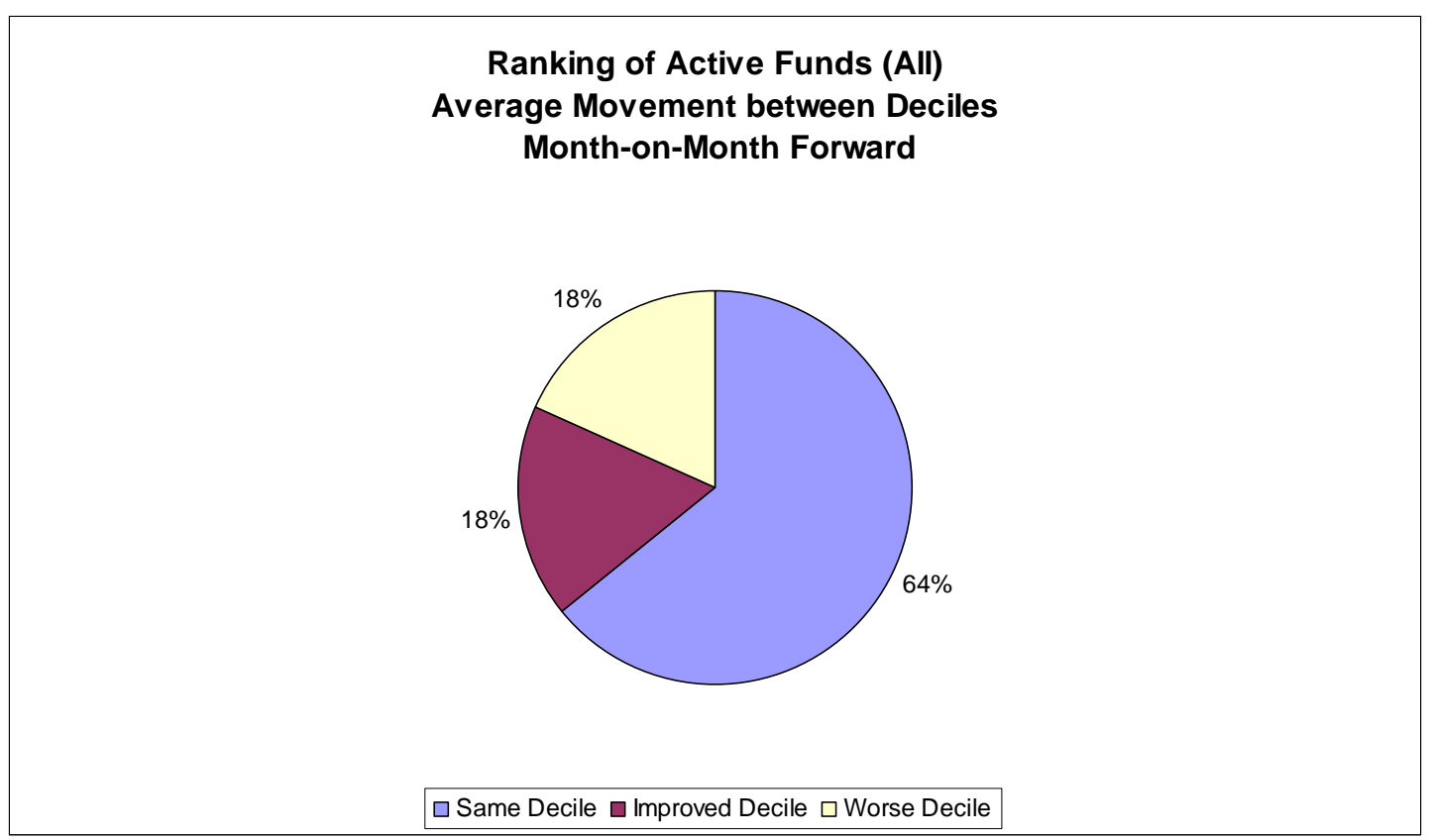

Figure 4: Tendency of actively managed funds to move between deciles on a month-to-month basis

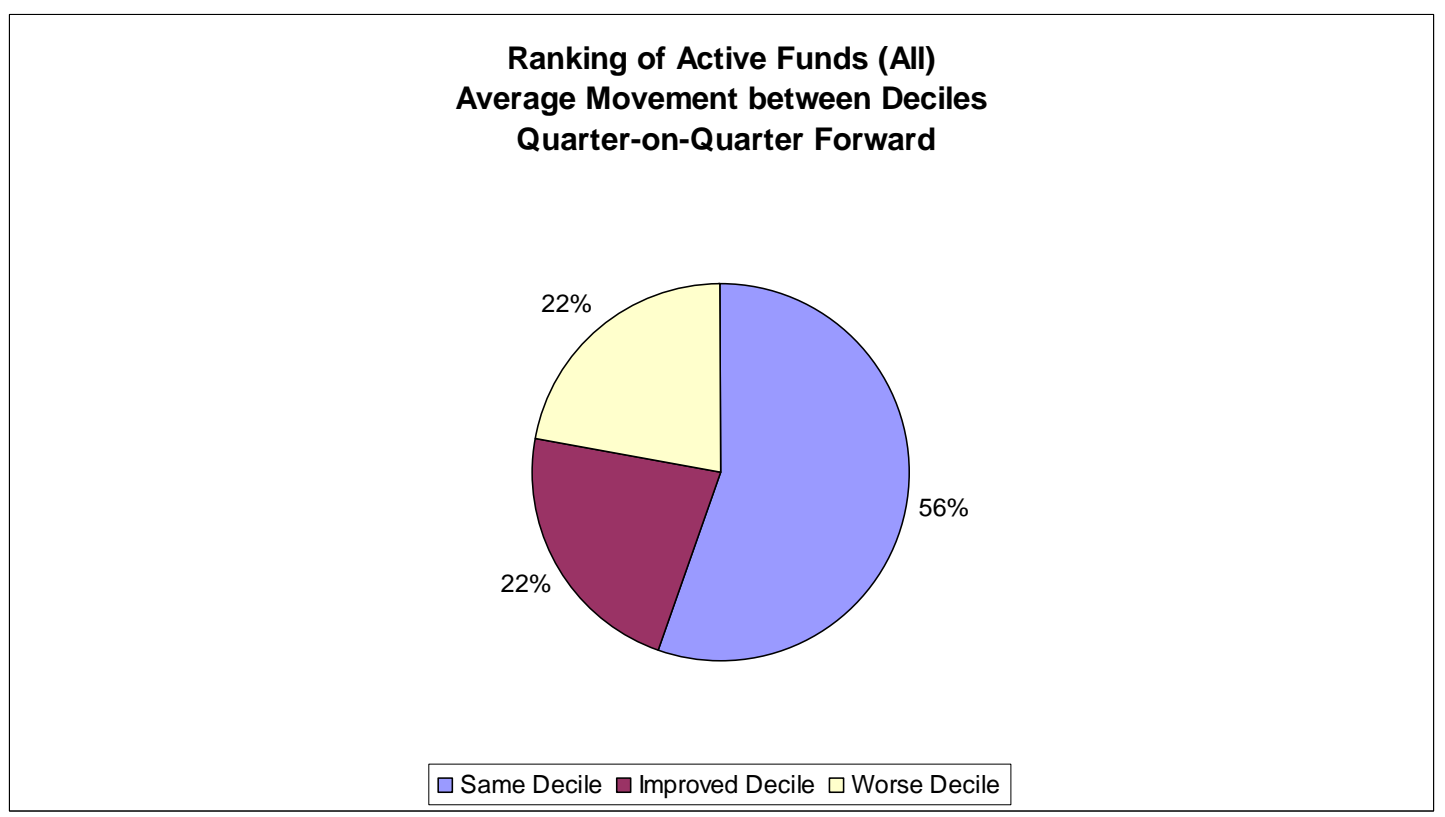

Figure 5: Tendency of actively managed funds to move between deciles on a quarterly basis 


\section{Ranking of Active Funds (All) \\ Average Movement between Deciles}

Year-on-Year Forward

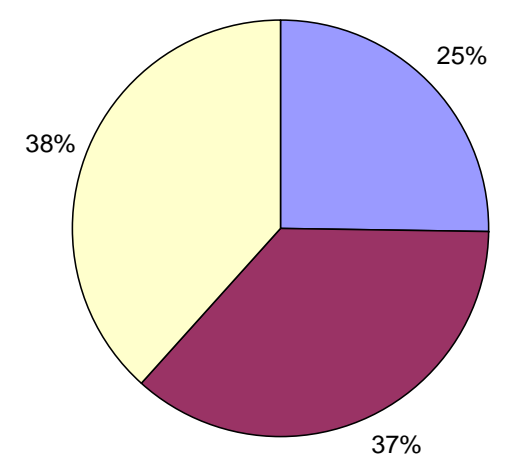

$\square$ Same Decile $\square$ Improved Decile $\square$ Worse Decile

Figure 6: Tendency of actively managed funds to move between deciles on a yearly basis

\section{Ranking of Active Funds (All) \\ Average Movement between Deciles \\ Three Year-on-Three Year Forward}

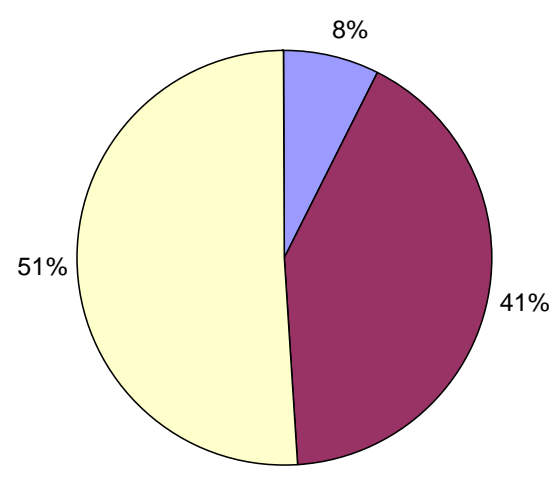

$\square$ Same Decile $\square$ Improved Decile $\square$ Worse Decile

Figure 7: Tendency of actively managed funds to move between deciles on a three-yearly basis 


\section{Summary}

Results from the study have shown similar trends than those established in international and local studies. Short-term persistence in performance return was found, but in general it did not exhibit any long-term predictability value.

A few funds showed remarkable persistence in keeping their performance in the top quartiles or alternatively to beat the index on a regular basis. However, in similar style some funds showed persistence in underperforming. The rest delivered a wide dispersion of relative performance.

Index investing ranked at about the $60^{\text {th }}$ percentile of active fund performance over the various investment periods, but showed large deviations in performance ranking over time. Nonetheless, its average ranking of the $60^{\text {th }}$ percentile confirms that index investing indeed yields better-thanaverage results over time.

No infallible method exists to identify those active managers in advance that will substantially outperform the index. One possible alternative would have been to evaluate the past performances of active managers over time whereby the consistency of a fund manager or company can be evaluated against complete randomness that would have prevailed if no manager skills were present.

Probably more important is to gather information from active managers in terms of their investment philosophies, processes and styles to form an opinion about the capabilities of the manager to deliver out-performance over time.

Furthermore, selection of active managers should focus on those managers that do not necessarily replicate the market closely and whose portfolios could deviate substantially from the index. Hereby a costly duplication of the index strategy is prevented and fees are rather paid for managers' skills to identify stocks that offer exceptional value going forward. For example, investment styles such as value investing or small capitalisation styles could be combined with index investing.

\section{References}

Bradfield, D. \& Swartz, J. 2001. 'Recent evidence on the persistence of fund performance - a note,' South African Journal of Accounting Research, 15(2):99-109.

Carhart, M.M. 1997. 'On persistence in mutual fund performance’, The Journal of Finance, 52(1):57-82.

Chavalier, J. \& Ellison, G. 1999. 'Are some mutual fund managers better than others?' The Journal of Finance, 54(3):875-899.

Elton, E.J. Gruber, M.J. \& Blake, C.R. 1996. 'The persistence of risk-adjusted mutual fund performance,' Journal of Business, 69(2):133-157.

Gopi, Y., Bradfield, D. \& Maritz, J. 2004. 'Has persistence persisted? Evidence from unit trusts,' Cadiz Quantitative
Research Report, June, 1-20, [online] URL: http://www.cadiz.co.za.

Hendricks, D., Patel, J. \& Zeckhauser, R. 1993. 'Hot hands in mutual funds: Short-run persistence of relative performance, 1974-1988,' The Journal of Finance, 48(1):93-122.

Goetzmann, W.N. \& Ibbotson, R.G. 1994. 'Do winners repeat?' The Journal of Portfolio Management, 20(2):9-18.

Kahn, R.N. \& Rudd, A. 1995. 'Does historical performance predict future performance?’ Barra Newsletter, Spring, [online]

URL:http://www.barra.com/research/BarraPub/hpp-n.aspx Accessed 10 July 2004.

Oosthuizen, H.R. \& Smit, E. v.d. M. 2002. 'South African unit trusts: Selection ability and information effects,' Journal for Studies in Economics and Econometrics, 26(3):19-41.

Zheng, L. 1999. 'Is money smart? A study of mutual fund investors' fund selection ability’, The Journal of Finance, 54(3):901-933. 
